\title{
Persidangan Tanpa Kehadiran Dokter Terlapor dalam Penanganan Kasus Pelanggaran Etik Kedokteran
}

\author{
Anna Rozaliyani ${ }^{\mathrm{1}, 2}$, Broto Wasisto ${ }^{\mathrm{I}, 3}$, Nurfanida Librianty $^{\mathrm{T}, 4}$ \\ ${ }^{\mathrm{I}}$ Majelis Kehormatan Etik Kedokteran Pengurus Besar Ikatan Dokter Indonesia \\ ${ }^{2}$ Departemen Parasitologi, Fakultas Kedokteran Universitas Indonesia \\ ${ }^{3}$ Ikatan Konsultan Kesehatan Indonesia (Ikkesindo) \\ ${ }^{4}$ Fakultas Kedokteran Universitas Pembangunan Nasional Veteran Jakarta
}

\begin{abstract}
Kata Kunci
In absentia, putusan, sidang etik

Korespondensi

contact@ilmiah.id

Publikasi

(C) $2018 \mathrm{JEKI} /$ ilmiah.id

DOI

I0.26880/jeki.v2i2.19

Tanggal masuk: ${ }_{4} 4$ April 2018

Tanggal ditelaah: 6 Mei 2018

Tanggal diterima: 10 Mei 2018

Tanggal publikasi: 12 Juni 2018

Abstrak Jika seorang dokter diduga melakukan pelanggaran etika kedokteran, maka Majelis Kehormatan Etik Kedokteran (MKEK) yang merupakan badan otonom di bawah Ikatan Dokter Indonesia (IDI) akan memanggil dokter yang bersangkutan untuk memberikan klarifikasi dan/atau mempertanggungjawabkan perilakunya tersebut. Apabila dokter teradu tidak dapat hadir tanpa alasan yang jelas setelah tiga kali pemanggilan, maka penanganan kasus dapat dilanjutkan tanpa kehadiran dokter teradu (inabsentia). Walaupun persidangan inabsentiamemastikan keberlanjutan pencapaian keadilan, proses persidangan ini juga masih mengundang kontroversi. Tanpa kehadiran dokter teradu, maka dokter tersebut kehilangan haknya untuk membela diri secara langsung. Untuk menjamin tidak terjadinya pelanggaran hak bagi dokter teradu dan mencapai hasil persidangan yang adil, maka perlu dilakukan tinjauan lebih lanjut untuk menetapkan persyaratan dan pelaksanaan persidangan in absentia.
\end{abstract}

\begin{abstract}
When a doctor is suspected of violating medical ethics, the Medical Ethics Council of Honor (MKEK), an autonomous body under the Indonesian Doctors Association (IDI), will summon the concerned doctor to clarify and/or take responsibility for his behavior. If the doctor does not answer after three summons, then the trial may proceed without his/her presence. Although this "trial in absentia" ensures the continuation of justice, such trial is still controversial. Without the presence of concerned doctor, he/she loses the right for defense. To ensure that no infringement of such rights and to achieve fair trial results, further review is required to establish the requirements and implementation of trial in absentia.
\end{abstract}

\section{PENDAHULUAN}

Profesi dokter merupakan moral community (komunitas moral) yang mendapatkan kepercayaan besar untuk menangani kondisi kesehatan seseorang. Dalam hal ini profesi dokter diatur oleh aspek etik dan hukum yang keduanya berjalan seiring dan sulit dipisahkan. Pelanggaran etik pada umumnya hanya memberikan sanksi moral, tetapi sanksi tersebut dipandang memiliki konsekuensi lebih berat dalam dunia kedokteran dibandingkan sanksi disiplin profesi. Sanksi disiplin bersifat administratif, dapat berupa peringatan, re- schooling (wajib mengikuti pendidikan atau pelatihan tertentu), hingga pencabutan ijin praktik. Penetapan sanksi tersebut bertujuan untuk memastikan masyarakat mendapatkan pelayanan kesehatan yang layak dari dokter berkompetensi baik. ${ }^{1}$ Selain itu dapat dilakukan peninjauan ulang kesalahan atau ketidakpuasan dalam pelayanan tersebut, sehingga keadilan dan perbaikan pelayanan kesehatan dapat dicapai.

Di Indonesia, pembimbingan, pengawasan dan penilaian kode etik profesi diatur MKEKyang merupakan badan otonom di bawah IDI. Jika seorang dokter diduga melakukan pelanggaran 
etika kedokteran, maka MKEK akan memanggil dokter yang bersangkutan untuk memberikan klarifikasi dan atau mempertanggungjawabkan perilakunya tersebut. Proses penanganan kasus dilakukan dalam persidangan yang bersifat khas profesi.

Dalam penanganan dokter teradu mulai tahap penelaahan sampai dengan penjatuhan sanksi etik, MKEK menggunakan asas praduga tak bersalah. Sanksi terhadap dokter pelanggar etik bersifat pembinaan dan ditetapkan oleh majelis pemeriksa Divisi Kemahkamahan MKEK. ${ }^{1}$ Penetapan sanksi dilakukan melalui urutan kegiatan penelaahan kasus yang dilakukan sistematis. Penelaahan dimulai dengan mempelajari keabsahan surat pengaduan, dilanjutkan dengan mengumpulkan berbagai barang bukti lengkap, termasuk memberikan kesempatan dokter teradu didampingi oleh pembela, dalam hal ini Biro Hukum Pembinaan dan Pembelaan Anggota (BHP2A) atau perangkat dan jajarannya, atau perorangan anggota IDI yang dinilai kompeten dan memenuhi syarat yang telah ditetapkan.

Pada situasi dokter teradu tidak hadir di persidangan karena berbagai alasan, maka diupayakan pemanggilan ulang. Apabila dokter teradu tetap tidak dapat hadir tanpa alasan yang jelas setelah tiga kali pemanggilan, maka persidangan dapat dilanjutkan tanpa kehadiran dokter teradu, atau dikenal sebagai persidangan in absentia. Hal tersebut dilakukan untuk memastikan keberlanjutan proses pencapaian keadilan. Namun demikian, persidangan in absentia masih mengundang berbagai kontroversi. Tanpa kehadiran dokter teradu, maka dokter tersebut secara langsung akan kehilangan kesempatan atau hak untuk membela diri. Tulisan ini bermaksud untuk meninjau proses persidangan in absentia dalam sidang etik kedokteran serta kontroversi yang menyertainya.

\section{HASIL DAN PEMBAHASAN}

\section{Fungsi MKEK}

Pedoman Organisasi dan Tata Laksana (Ortala) MKEK pasal 1 ayat 3 menyebutkan bahwa MKEK merupakan salah satu badan otonom IDI yang dibentuk secara khusus di tingkat Pusat, Wilayah dan Cabang untuk menjalankan tugas kemahkamahan profesi, pembinaan etika profesi dan atau tugas kelembagaan dan ad hoc lainnya dalam tingkatannya masing-masing. Dalam hal ini MKEK dibagi menjadi MKEK wilayah yang berfungsi untuk melaksanakan tugas MKEK di provinsi masing-masing.

Beberapa tugas MKEK wilayah di antaranya adalah memeriksa, menyidangkan, membuat putusan setiap konflik etikolegal yang berpotensi menimbulkan sengketa medik di antara perangkatdan jajaran IDI, maupun antara dokter pengadunya yang belum atau tidak ditangani Majelis Kehormatan Disiplin Kedokteran Indonesia (MKDKI) sesuai pasal 6 ayat 4. Selain itu MKEK juga memiliki kewenangan untuk menyampaikan pertimbangan pelaksanaan etika kedokteran dan usul secara lisan dan atau tertulis, baik diminta atau tidak diminta kepada pengurus IDI setingkat (pasal 9 ayat 1), ikut mempertahankan hubungan dokter dan pasien sebagai hubungan kepercayaan (pasal 10 ayat 1), membantu penyelenggaraan uji kompetensi khusus bidang etika kedokteran oleh perangkat dan jajaran IDI setingkat maupun institusi kedokteran lain yang memerlukannya (pasal 10 ayat 4), membantu IDI setingkat dalam menyelesaikan dan menyidangkan kasus status keanggotaan organisasi profesi dokter (pasal 10 ayat 6), serta bertanggung jawab dalam menjabarkan kebijakan dan garis-garis besar program pembinaan etika kedokteran seluruh Indonesia dan mengkoordinasikannya untuk tingkat provinsi (pasal 18 ayat 2). ${ }^{2}$

\section{Proses Pengaduan Sidang MKEK}

Proses pengaduan sidang MKEK telah diatur dalam Pasal 22 Pedoman MKEK. Pengaduan disampaikan melalui IDI atau MKEK tingkat Cabang atau Wilayah, yang 
dapat berasal secara langsung dari pasien, teman sejawat, tenaga kesehatan lainnya, institusi kesehatan, atau organisasi profesi; dan dapat pula diperoleh melalui temuan IDI setingkat dan Divisi Pembinaan Etika Profesi MKEK setingkat, rujukan atau banding dari MKEK Cabang untuk MKEK Wilayah atau MKEK Wilayah untuk MKEK Pusat, hasil verifikasi MKDKI atau lembaga disiplin profesi atau lembaga pembinaan etika, atau hal lainnya yang ditentukan kemudian oleh MKEK Pusat.

Setelah pengaduan dianggap lengkap atau sah, selanjutnya dilakukan pemanggilan pengadu dan teradu. Pasal 22 Ayat 7 dan 8 Pedoman MKEK menyatakan bahwa pemanggilan pengadu dan teradu dapat dilakukan sampai 3 kali, namun apabila pengadu tetap tidak dapat hadir tanpa alasan yang sah maka pengaduan dibatalkan; sebaliknya jika teradu tetap tidak dapat datang tanpa alasan yang sah, maka penanganan kasus dapat dilanjutkan tanpa kehadiran teradu dan putusan yang ditetapkan dinyatakan sah dan tidak dapat dilakukan banding. ${ }^{2}$

\section{Menelisik Kontroversi Persidangan In Absentia}

Pada esensinya, persidangan adalah suatu wadah bagi teradu untuk membela diri dari bukti yang menjatuhkannya dan menyampaikan pernyataan dari sisinya. Dengan demikian, kehadiran teradu sepatutnya menjadi persyaratan persidangan yang adil. Berbagai negara di dunia memiliki kebijakan berbedabeda dalam hal menyikapi persidangan in absentia. Di Australia, hasil persidangan in absentia memiliki batasan hukuman, yaitu tiga tahun penjara. Di Jerman, hasil persidangan in absentia tidak boleh memberikan hukuman penjara sama sekali. Sementara itu, Afrika Selatan hanya memperbolehkan pelaksanaan persidangan in absentia dalam kondisi teradu dikeluarkan dari persidangan karena perilaku tidak baik.

Artikel 14 dari The International Covenant on Civil and Political Rights menyatakan bahwa teradu harus diadili dengan kehadirannya dalam persidangan. ${ }^{3}$ Namun demikian, United Nations for Human Rights Committee
(UNHCR) dan European Court of Human Rights (ECtHR) menyatakan bahwa persidangan in absentia dapat dilaksanakan dalam beberapa kondisi, yaitu: (1) teradu telah mendapatkan notifikasi akan persidangan, (2) teradu harus direpresentasikan secara legal pada persidangan dan memiliki bantuan pengacara, dan (3) teradu mempunyai hak untuk pengadilan ulangan atau pengadilan ex novo dengan kehadirannya. Penjaminan bahwa teradu telah mengetahui dan mendapatkan pemberitahuan akan persidangan, diharapkan telah disampaikan pemerintah negara bagian secara resmi, misalnya pengumuman melalui koran. Pengacara yang ditunjuk untuk merepresentasikan teradu pun harus mampu memenuhi tugasnya secara efektif dan memiliki kompetensi sesuai dengan level kriminal yang disidangkan. Kemudian, hak untuk pengadilan ulang memiliki artian yang berbeda antara UNHCR dan ECtHR. Pengadilan ulang menurut UNHCR bersifat ex novo, sedangkan dari sudut pandang ECtHR bersifat de novo atau berdasarkan fakta. Proses pengadilan ulang pun masih menimbulkan pertanyaan akan organisasi yang sesuai untuk menjalankan pengadilan tersebut dan pihak yang bertanggung jawab untuk mendanai. ${ }^{4}$

Di Filipina, persidangan in absentia boleh dilaksanakan dalam kondisi tertentu, sebagaimana tertera dalam artikel 3, bagian 14, butir 2 Konstitusi Tahun 1987 yang menyatakan: In all criminal prosecutions, the accused shall be presumed innocent until the contrary is proved, and shall enjoy the right to be heard by himself and counsel, to be informed of the nature and cause of the accusation against him, to have a speedy, impartial, and public trial, to meet the witnesses face to face, and to have compulsory process to secure the attendance of witnesses and the production of evidence in his behalf. However, after arraignment, trial may proceed notwithstanding the absence of the accused: Provided, that he has been duly notified and his failure to appear is unjustifiable." ${ }^{5}$ Persidangan in absentia hanya dapat dilaksanakan apabila terdapat tuduhan, teradu telah mendapat pemberitahuan, dan ketidakhadiran teradu tidak dapat diterima karena alasan yang tidak jelas. Di sisi lain, argumen akan hilangnya hak teradu untuk membela diri dalam persidangan 
in absentia dipatahkan dengan aturan 115 butir 1 Revised Rules on Criminal Procedure yang menyatakan bahwa ketidakhadiran teradu tanpa alasan yang dapat diterima, dianggap sebuah pengabaian akan haknya sendiri. ${ }^{6}$

Berlangsungnya persidangan in absentia menunjukkan bahwa teradu tidak dapat menunda proses peradilan dengan memilih untuk tidak hadir dalam sidang. Persidangan in absentia mendukung fungsi persidangan untuk mengusung kebenaran dan keadilan. Penundaan pelaksanaan sidang tidak hanya membuang waktu publik, sumber daya dan dana, tetapi teradu yang berada dalam tahanan pun dirugikan. Persidangan yang terus berjalan bagi teradu yang melarikan diri, berdampak positif dalam upaya penegakan hukum. Hal itu menghindari kesan publik bahwa teradu mendapat keuntungan atas pelarian dirinya. Apabila korban atau pengadu mendapatkan kompensasi atas klaimnya, maka persidangan in absentia juga memastikan kompensasi tersebut tersampaikan dengan semestinya.

Korban, pengadu, dan publik juga memiliki hak untuk mendapatkan kejelasan atas suatu kasus. Hal itu hanya dapat disampaikan melalui persidangan in absentia jika teradu tak kunjung hadir, atau bahkan tidak mungkin hadir, dalam persidangan. Pada Mei 2008, sebuah persidangan dilaksanakan di Court of Appeal of Paris, untuk mengadili 15 mantan pejabat tingkat tinggi yang berkuasa selama era diktator Augusto Pinochet di Chile pada 1973-1990, yang diduga berkomplot untuk menyelenggarakan kudeta dan melenyapkan 4 orang pejabat dari kubu oposisi. Walaupun tuduhan, tanggal persidangan dan daftar saksi telah disampaikan; tetapi tidak ada satu pun dari 15 teradu yang hadir, bahkan 4 tersangka telah meninggal saat sidang dilakukan, termasuk Pinochet sendiri. Namun demikian, pada akhirnya keluarga korban beranggapan bahwa persidangan in absentia tersebut telah memberikan kepuasan signifikan. ${ }^{?}$

\section{Persidangan In Absentia di Mata Hukum Indonesia}

Persidangan dalam perkara pidana konsep in absentia adalah konsep di mana terdakwa telah dipanggil secara sah dan tidak hadir di persidangan tanpa alasan yang sah, sehingga pengadilan melaksanakan pemeriksaan di pengadilan tanpa kehadiran terdakwa. Berdasarkan Pasal 196 ayat (1) UU No. 8 Tahun 1981 tentang Hukum Acara Pidana (KUHAP) yang menyatakan "Pengadilan memutus perkara dengan hadirnya terdakwa kecuali dalam hal undang-undang ini menentukan lain". ${ }^{8}$ Surat Edaran Mahkamah Agung No. 6 Tahun 1988 tentang Penasihat Hukum atau Pengacara yang Menerima Kuasa dari Terdakwa/Terpidana "In Absentia" yang memerintahkan hakim untuk menolak penasihat hukum/pengacara yang mendapat kuasa dari terdakwa yang sengaja tidak mau hadir dalam pemeriksaan pengadilan sehingga dapat menghambat jalannya pemeriksaan pengadilan dan pelaksanaan putusannya. $^{9}$

Ketentuan Pasal 196 KUHAP jika terdapat suatu penyimpangan dalam perkara pelanggaran lalu lintas sebagaimana diatur Pasal 213 KUHAP yang menyatakan bahwa "terdakwa dapat menunjuk seorang dengan surat untuk mewakilinya di sidang”. Selain itu, Pasal 214 ayat (1) dan ayat (2) KUHAP menyatakan: Jika terdakwa atau wakilnya tidak hadir di sidang, pemeriksaan perkara dilanjutkan. Dalam hal putusan diucapkan di luar hadirnya terdakwa, surat amar putusan segera disampaikan kepada terpidana. $^{8}$

Berdasarkan Surat Edaran Mahkamah Agung No. 9 Tahun 1985 tentang Putusan yang Diucapkan di Luar Hadirnya Terdakwa, Mahkamah Agung berpendapat bahwa perkara-perkara yang diperiksa dengan Acara Pemeriksaan Cepat (baik perkara tindak pidana ringan maupun perkara pelanggaran lalu lintas jalan) dapat diputus di luar hadirnya terdakwa (verstek). ${ }^{10}$ Jadi, hukum acara pidana tidak hanya mengakui keberadaan persidangan secara in absentia untuk perkara pelanggaran lalu lintas jalan, melainkan berlaku juga bagi perkara tindak pidana ringan (lihat Pasal 205 KUHAP).

Persidangan in absentia secara khusus diatur dalam beberapa Undang-Undang (UU). Seperti pada UU No. 20 Tahun 2001 yang menyatakan dalam hal terdakwa telah dipanggil secara sah, dan tidak hadir di sidang pengadilan 
tanpa alasan yang sah, maka perkara dapat diperiksa dan diputus tanpa kehadirannya. ${ }^{11}$ UU No. 8 Tahun 2010 tentang Pencegahan Dan Pemberantasan Tindak Pidana Pencucian Uang yang menyatakan dalam hal terdakwa telah dipanggil secara sah dan patut namun tidak hadir di sidang pengadilan tanpa alasan yang sah, perkara dapat diperiksa dan diputus tanpa hadirnya terdakwa. ${ }^{12}$ UU No. 31 Tahun 2004 tentang Perikanan sebagaimana telah diubah dengan UU No. 45 Tahun 2009 yang menyatakan Pemeriksaan di sidang pengadilan dapat dilaksanakan tanpa kehadiran terdakwa. ${ }^{13}$ Dalam Surat Edaran Mahkamah Agung No. 03 Tahun 2007 tentang Petunjuk Pelaksanaan Undang-Undang No. 31 Tahun 2007 tentang Perikanan, disebutkan bahwa pemeriksaan di sidang pengadilan dapat dilaksanakan tanpa kehadiran terdakwa, sebagaimana ditentukan dalam Pasal 79 Undang-Undang Nomor 31 Tahun 2004 tentang Perikanan adalah dalam pengertian perkara in absentia, yaitu terdakwa sejak sidang pertama tidak pernah hadir di persidangan. ${ }^{14,15}$

Dengan demikian, dalam perkara tindak pidana korupsi, tindak pidana pencucian uang, serta tindak pidana perikanan dimungkinkan pula suatu persidangan dan pembacaan putusan tanpa dihadiri terdakwa. Bahkan dalam hukum acara perdata, pengaturan in absentia juga terdapat dalam Pasal 125 Herzien Inlandsch Reglement (HIR) yang menyatakan apabila terhadap seorang tergugat telah dilakukan pemangilan secara patut namun panggilan pengadilan tidak dipenuhi, maka perkara dapat diputus tanpa kehadiran tergugat. ${ }^{16}$ Persidangan secara in absentia juga dikenal dalam Peradilan Tata Usaha Negara. UU No. 9 Tahun 2004 dan UU No. 51 Tahun 2009, menyatakan "Dalam hal setelah lewat dua bulan sesudah dikirimkan dengan surat tercatat, penetapan sebagaimana dimaksud dalam ayat (1) tidak diterima berita, baik dari atasan tergugat maupun dari tergugat, maka Hakim Ketua Sidang menetapkan hari sidang berikutnya dan pemeriksaan sengketa dilanjutkan menurut acara biasa, tanpa hadirnya tergugat". ${ }^{17,18}$

\section{KESIMPULAN}

Pelaksanaan sidang in absentia dapat dilakukan jika memenuhi persyaratan dan sesuai dengan regulasi yang berlaku. Penanganan kasus dapat terus dilakukan jika teradu telah dipanggil secara sah sebanyak tiga kali, tetapi tetap tidak hadir dengan alasan yang sah. Regulasi dalam Pedoman MKEK dalam pelaksanaan persidangan in absentia adalah sebuah tindakan untuk mencapai keadilan dan meningkatkan pelayanan kesehatan kepada masyarakat.

\section{KONFLIK KEPENTINGAN}

Tidak ada konflik Kepentingan

\section{REFERENSI}

1. Rozaliyani A, Meilia PDI, Librianty N. Prinsip penetapan sanksi bagi pelanggaran etik kedokteran. J Etik Ked Ind. 2018 Mar 19;2(1):19. https://doi.org/10.26880/jeki.v2i1.11.

2. Purwadianto A, editor. Pedoman organisasi dan tata laksana kerja Majelis Kehormatan Etik Kedokteran. Jakarta: Majelis Kehormatan Etika Kedokteran Ikatan Dokter Indonesia; 2008.

3. United Nations General Assembly. International covenant on civil and political rights. 1966.

4. Klerks A. Trials in absentia in international (criminal) law. Tilburg University; 2008.

5. Republik Filipina. The constitution of the Republic of the Philippines. 1987.

6. Republik Filipina. Revised rules of criminal procedure. Rules 110 to 127.2000. 
7. International Federation for Human Rights. A historical trial in France on crimes against humanity committed under Chilean military dictatorship [Internet]. 2008 Feb 12 [disitasi 2018 Apr 11]. Diunduh dari: https:// www.fidh.org/en/issues/litigation/litigationagainst-individuals/Pinochet-and-others-Case/ A-HISTORICAL-TRIAL-IN-FRANCE-ON

8. Undang-Undang Republik Indonesia nomor 8 tahun 1981 tentang hukum acara pidana. 1981.

9. Surat Edaran Mahkamah Agung Republik Indonesia nomor 6 tahun 1988 tentang penasehat hukum atau pengacara yang menerima kuasa dari terdakwa/terpidana "in absentia." 1988.

10. Surat Edaran Mahkamah Agung Republik Indonesia nomor 9 tahun 1985 tentang putusan yang diucapkan di luar hadirnya terdakwa. 1985.

11. Undang-Undang Republik Indonesia nomor 20 tahun 2001 tentang perubahan atas Undang-Undang nomor 31 tahun 1999 tentang pemberantasan tindak pidana korupsi. 2001.

12. Undang-Undang Republik Indonesia nomor 8 tahun 2010 tentang pencegahan dan pemberantasan tindak pidana pencucian uang. 2010.

13. Undang-Undang Republik Indonesia nomor 45 tahun 2009 tentang perubahan atas Undang-Undang nomor 31 tahun 2004 tentang perikanan. 2009.

14. Surat Edaran Mahkamah Agung Republik Indonesia nomor 03 tahun 2007 tentang petunjuk pelaksanaan Undang-Undang nomor 31 tahun 2007 tentang perikanan. 2007.

15. Undang-Undang Republik Indonesia nomor 31 tahun 2004 tentang perikanan. 2004.

16. Herzien Inlandsch Reglement (H.I.R)

(S. 1941-44) tentang Reglemen Indonesia yang Diperbaharui (R.I.B.). 1941.
17. Undang-Undang Republik Indonesia nomor 9 tahun 2004 tentang perubahan atas Undang-Undang nomor 5 tahun 1986 tentang peradilan tata usaha negara. 2004.

18. Undang-Undang Republik Indonesia nomor 51 tahun 2009 tentang perubahan kedua atas Undang-Undang nomor 5 tahun 1986 tentang peradilan tata usaha negara. 2009. 